\title{
Extra ocular sebaceous adenocarcinoma in HIV-positive patient - Case report
}

\author{
Adenocarcinoma sebáceo extra-ocular em paciente HIV positivo - Relato de caso
}

\author{
Carla Kellen da Silva Menezes ${ }^{1}$ \\ Alex Panizza Jalkh ${ }^{3}$ \\ Thalita Gomes Martins ${ }^{5}$
}

\author{
Nathália Matos Gomes ${ }^{2}$ \\ Emily dos Santos Franco
}

DOI: $h$ ttp://dx.doi.org/10.1590/abd1806-4841.20132476

\begin{abstract}
Sebaceous adenocarcinoma is a rare adnexal tumor that can affect the skin and is divided into ocular, a more common form and extra ocular, of a rarer occurrence. We report the case of a patient diagnosed with Acquired Immune Deficiency Syndrome (AIDS) who developed an extra ocular, bulky and fast-growing sebaceous adenocarcinoma on the face. The literature has suggested that transplanted patients and HIV-positive patients have an excess risk for developing adnexal tumors, including sebaceous adenocarcinoma.

Keywords: Adenocarcinoma, sebaceous; HIV; Immunosuppression

Resumo: Adenocarcinoma sebáceo é um tumor anexial raro que pode envolver a pele e é dividido em ocular, mais comum e extraocular, mais raro. Relatamos o caso de um paciente com diagnóstico de Síndrome da Imunodeficiência Adquirida que desenvolveu um adenocarcinoma sebáceo extra-ocular, na face, volumoso, de rápido crescimento. A literatura tem sugerido que pacientes transplantados e portadores do vírus da imunodeficiência humana têm um excesso de risco para o desenvolvimento de tumores anexiais, incluindo o Adenocarcinoma sebáceo.

Palavras-chave: Adenocarcinoma sebáceo; HIV; Imunossupressão
\end{abstract}

\section{INTRODUCTION}

Sebaceous adenocarcinoma (ACS) is a rare adnexal tumor that may affect the skin, and that is usually classified into two categories: ocular and extra ocular..$^{1-3}$

It frequently appears on the ocular region, particularly on the eyelids, in $75 \%$ of the cases; however it can occur in other body parts, as well..$^{1,24}$

Extra ocular tumors correspond roughly to a quarter of all cases and are mostly located on the head and neck areas, which have larger quantities of sebaceous glands. ${ }^{1-3}$

The incidence of extra ocular ACS is higher in men, with a rate as high as 2:1, occurring commonly during the seventh decade of life..$^{1,3,5}$
Clinically these tumors appear, in general, as a nodular or cystic nodular mass, measuring up to 8 centimeters, with poorly defined margins, and tending to ulcerate. ${ }^{1,2,3,4,6}$

It is suggested that, patients submitted to transplants or those diagnosed with HIV-positive have an excess of risk of developing adnexal tumors, including ACS, however the reasons for this is not yet clearly elucidated. ${ }^{7}$

The goal of this report is to present the case of a patient, previously diagnosed with AIDS, who developed a facial extra ocular ACS and also to discuss the literature data regarding the mechanisms involved in the development of such neoplasms in HIV-positive patients.

Received on 22.01.2013.

Approved by the Advisory Board and accepted for publication on 20.05.2013.

Work performed at Dr. Heitor Vieira Dourado Amazonas Tropical Medicine Foundation (FMTAM) - Manaus (AM), Brazil.

Financial Support: None

Conflict of Interest: None.

MD, resident on the Surgical Pathology program at Amazonas Federal University (UFAM) - Manaus (AM), Brazil.

MD, resident on the Dermatology program at Dr. Heitor Vieira Dourado Amazonas Tropical Medicine Foundation (FMTAM) - Manaus (AM), Brazil.

MD, Dermatologist, MSc in Infectious and Tropical Diseases, preceptor of the dermatology residents at Dr. Heitor Vieira Dourado Amazonas Tropical Medicine Foundation (FMTAM) - Manaus (AM), Brazil.

MD, resident on the Surgical Pathology program at Amazonas Federal University (UFAM) - Manaus (AM), Brazil.

MD, resident on the Surgical Pathology program at Amazonas Federal University (UFAM) - Manaus (AM), Brazil 


\section{CASE REPORT}

A forty-two year old male patient, diagnosed with AIDS on the previous year, sought medical attention after presenting with daily fever, watery diarrhea, generalized myalgia and weight loss for a week.

Besides these symptoms, the patient reported an asymptomatic facial mass, growing in the last four weeks.

On physical examination the patient had a poor general status, was emaciated and febrile. On the right mandibular region an exophytic tumor $(3 \times 1.5 \mathrm{~cm})$ was noticeable, presenting with an infiltrated base and exulcerated areas (Figure 1). The exam also detected generalized lymphadenomegaly.

Laboratory exams showed: HIV viral load: 55,986; CD4 count: 96; anemia (hemoglobin: $9.2 \mathrm{mg} / \mathrm{dl}$ ) and lactic dehydrogenase (LDH): $1,965 \mathrm{mg} / \mathrm{dl}$.

Tissue obtained from the excisional biopsy was stained with hematoxiline eosine (HE) and revealed an ulcerated neoplasm, formed by stacks of basaloid cells with eosinophilic cytoplasm, centered by a population of cells with micro vacuolated cytoplasm and irregular, hyperchromic nuclei with mitotic figures and necrotic areas, characteristics consistent with ACS (Figures 2 and 3).

To confirm the diagnosis, we performed an immunohistochemistry study (IMQ) that revealed expression of cytokeratin and protein p63 on the basaloid cells and EMA on the micro vacuolated cells, findings that were consonant with ACS (Figure 4).

During admission, a computerized tomography of the chest showed signs suggestive of either bronchiolitis or endobronchial dissemination of pulmonary tuberculosis. Therefore, treatment with antiretroviral therapy, antibiotics and COXCIP 4 (rifampicin, isoniazid, pyrazinamide and ethambutol) were initiated, however, there was a progressive deterioration on the clinical status and the patient died due to respiratory failure, after seventy days of hospitalization.

\section{DISCUSSION}

We report a case of a voluminous, fast-growing, facial ACS, in an HIV-positive patient. This tumor is characterized histologically by the proliferation of poorly delimitated dermic lobules, formed by basaloid cells and other more mature cells with an slightly vacuolized cytoplasm, separated by fibrovascular stroma without obvious desmoplasia. The central portions of these cellular nests may become necrotic, giving a comedo-like appearance. ${ }^{1,2}$

Special stains for lipids, such as black Sudan, may be used when there is fresh tissue available and they are often positive in ACS and negative in other

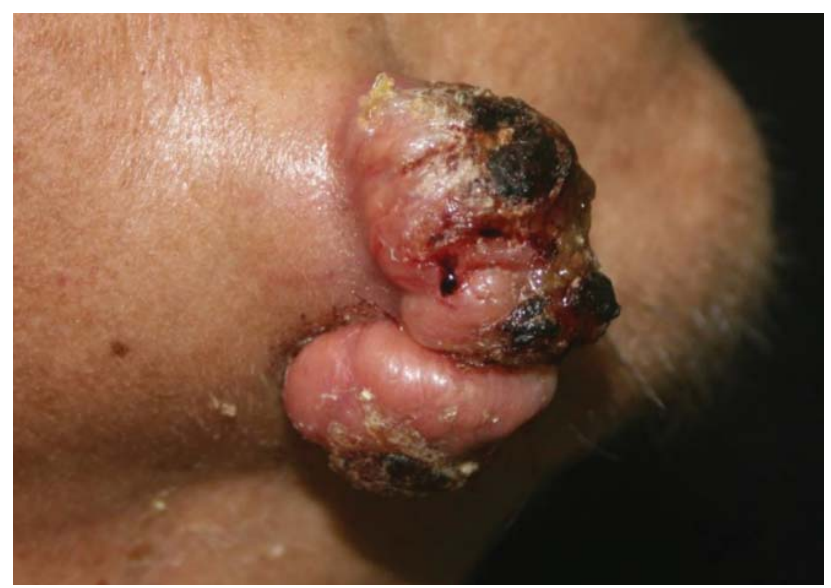

FIGURE 1: Extra ocular sebaceous adenocarcinoma: exophytic, voluminous, irregular tumoral lesion, with an infiltrated base and exulcerated areas presenting with hematic crusts on the surface. The lesion is located on the right mandibular area of an HIV-positive patient.

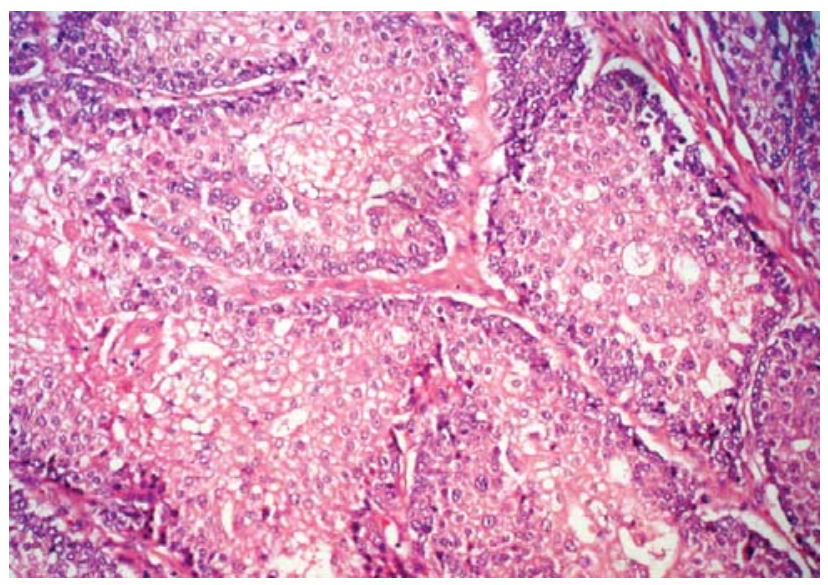

FIGURE 2: Sebaceous adenocarcinoma: poorly delimitated lobules formed by stacks of basaloid cells with eosinophilic cytoplasm, centered by a population of cells with micro vacuolated cytoplasm, and hyperchromic, irregular nuclei. (HE 20X)

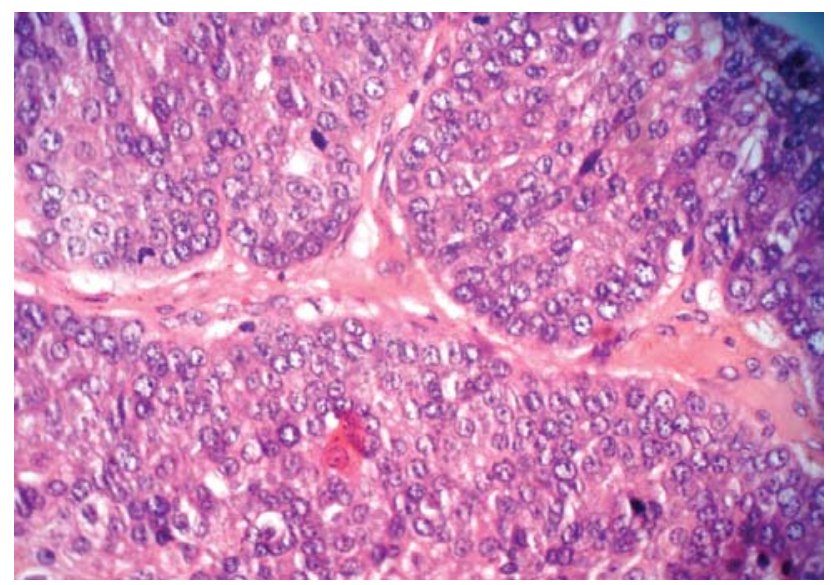

FIGURE 3: Sebaceous adenocarcinoma: presence of mitotic figures (HE 40x) 


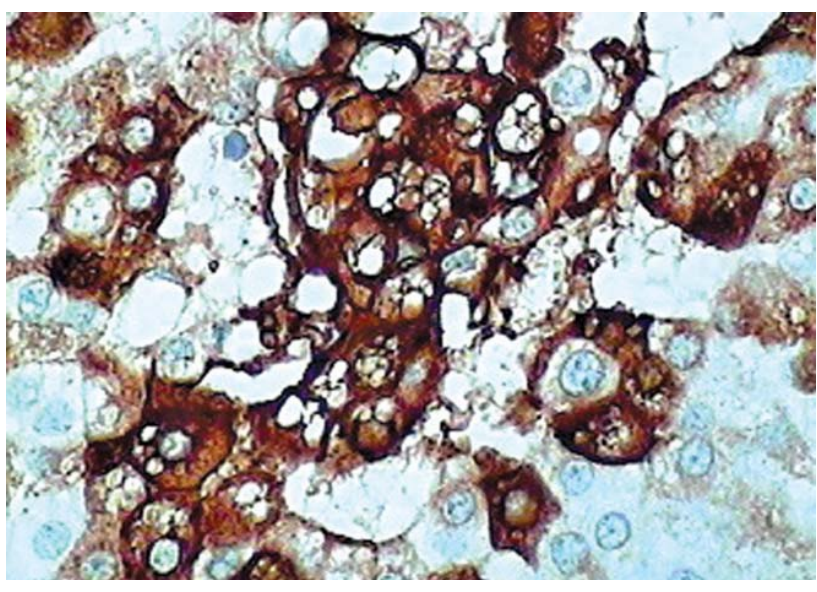

FIGURE 4: Sebaceous adenocarcinoma: immunohistochemistry study showing positivity for epithelial membrane antigen (EMA) on micro vacuolated cells

tumor such as clear-cell carcinoma, squamous-cell carcinoma (CEC) and hidradenocarcinoma, among others. ${ }^{1}$

Immunohistochemistry is usually unnecessary to diagnose ACS. Diagnosis may be obtained with HE, however, neoplastic cells are usually positive for epithelial membrane antigen (EMA), proteins p63 and p53, cytokeratin, the product of oncogene c-erb-2, glycoprotein EP4 BER and adipophilin, a more recent marker. ${ }^{1,3}$

Differential diagnosis for ACS are ample and include practically all skin clear-cell malignant tumors, such as balloon-cell melanoma (MCB), CEC, clear-cell basocellular carcinoma (CBC), and clear-cell eccrine carcinoma, among others. None of these neoplasms, however, except for $\mathrm{MCB}$, presents the same multivesicular, bubble-like, cytoplasmic vacuolization pattern seen in sebocytes. MCB is positive for protein S-100, HMB-45 or melanoma antigen recognized by T1-cells (MART-1). ${ }^{1,2}$

Basaloid ACS is also discernible from CBC with sebaceous differentiation, because its nuclei are more vesiculated than those of CBC. Besides, basaloid ACS's stroma is not fibromixoid and the number of sebocytes is small. In contrast, $\mathrm{CBC}$ with sebaceous differentiation presents with clusters of mature sebaceous elements. Both basaloid ACS and CBC with sebaceous differentiation express glycoprotein-EP4 BER on immunohistochemistry, but the differ in their expression of EMA. ACS is diffusely EMA-reactive, whilst the other one is either EMA-negative or only focally positive. ${ }^{2}$

This report presented the case of an HIV-positive patient with ACS. Medical literature suggests these patients have a higher risk of developing adnexal neoplasms (NA), including ACS, the causes for this, however are not yet elucidated.

It is known that chronic exposure to solar ultraviolet radiation is the main risk factor for developing several types of skin cancer and also that the evolution of these tumors in HIV-positive patients is related to the duration of the disease. ${ }^{7.8}$

A recent study demonstrated the higher incidence rates of Merkel cell carcinomas and NA, especially ACS, in patients with AIDS when compared to the population in general, suggesting that immunosuppression is an important risk factor for this neoplasms. ${ }^{7,89}$

In Japan, human papilloma virus (HPV) was linked to some cases of ACS. However, the same result was not found in the United States, where seven patients evaluated in a study were negative for $\mathrm{HPV} .^{10}$

These observations advocate that those tumors occur, at least in part, due to the loss of control of the immune system to an oncogenic virus, even though as a result of the rarity of these lesions, data are limited. ${ }^{7.8}$ Nonetheless, one cannot deny the relevance of HIVinduced immunosuppression in the etiology of these neoplasms.

NA in HIV-positive patients are scarcely represented in the world medical literature, therefore, we not only reported this case of an unusual tumor, but we propose that more cases might be documented and more studies performed on this topic, first and foremost to ensure a decrease in morbimortality and also a better understanding of the mechanisms involved. $\square$ 


\section{REFERENCES}

1. Calonje EJ, Brenn T, Lazar AJ, McKee PH. McKee's Pathology of the Skin With Clinical Correlations. Edinburgh: Elsevier/Saunders; 2012. p. 501-505.

2. Crowson AN, Magro CM, Piepkorn MW. Dermatophatology. In: Barnhill, RL, editor. Dermatopathology. New York: The McGraw-Hill Companies; 2010. p. 693-695.

3. Díez JRF. Neoplasias malignas de anexos cutáneos. Experiencia con 247 casos (Cutaneous adnexal malignant neoplasms. Experience of 247 cases - original in Spanish). Rev Latinoam Patol. 2011;1:19.

4. Eisen DB, Michael JD. Sebaceous lesions and their associated syndromes: Part I. J Am Acad Dermatol. 2009;61:549-60.

5. Dores GM, Curtis RE, Toro JR, Devesa SS, Fraumeni JF Jr. Incidence of cutaneous sebaceous carcinoma and risk of associated neoplasms: Insight into Muir-Torré syndrome. Cancer. 2008;113:3372-81.

6. Schlauder SM, Morgan MB. Cutaneous Neoplasms with Sebaceous Differentiation: A Review. Pathol Case Rev. 2007;2:79-85.

7. Lanoy E, Dores GM, Madeleine MM, Toro JR, Fraumeni JF Jr, Engels EA. Epidemiology of non-keratinocytic skin cancers among persons with acquired immunodeficiency syndrome in the U.S. AIDS. 2009;23:385-93.

8. Engels AE. Non-AIDS-defining malignancies in HIV-infected persons: etiologic puzzles, epidemiologic perils, and prevention opportunities. AIDS. 2009;23:875-85.

9. Lanoy E, Costagliola D, Engels EA. Skin cancers associated with HIV infection and solid organ transplant among elderly adults. Int J Cancer. 2010;126:1724-31.

10. Yen MT, Tse DT. Sebaceous Cell Carcinoma of the Eyelid and the Human Immunodeficiency Virus. Ophthal Plast Reconstr Surg. 2000;16:206-10.
MAILING ADDRESS:

Carla Kellen da Silva Menezes

Av. Pedro Teixeira, 25 - Dom Pedro I

69.040-000 - Manaus - AM

Brazil

E-mail: carlakmenezes@yahoo.com.br

How to cite this article: Menezes CK, Gomes NM, Jalkh AP, Franco ES, Martins TG. Extra ocular sebaceous adenocarcinoma in HIV-positive patient: a case report. An Bras Dermatol. 2013;88(6 Suppl 1):S19-22. 